Доктора наук
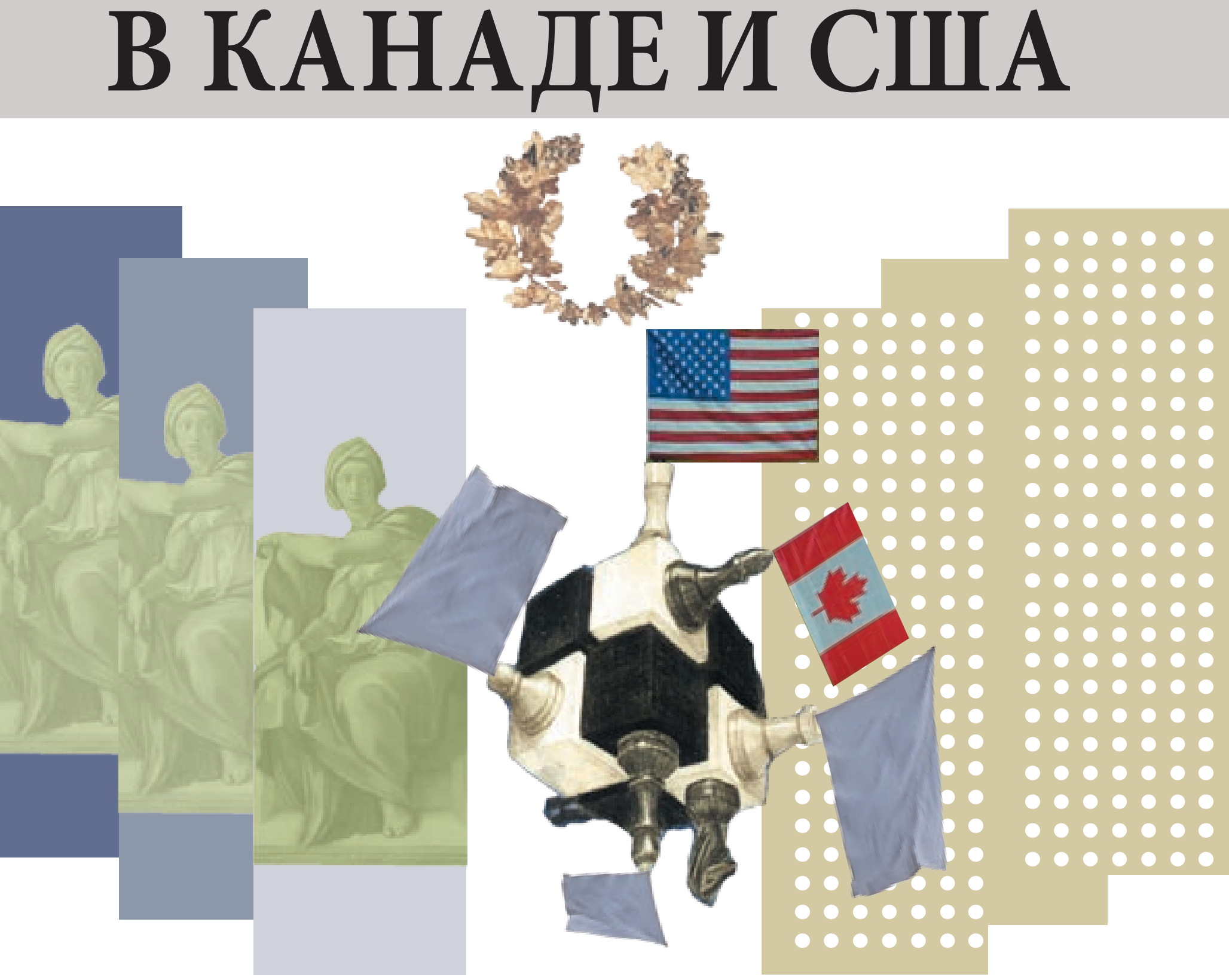

Д. Бутби

кто и почему едет в Северную Америку за степенью
$\mathbf{D}$ США статистическое изучение контингента спеВциалистов, получающих степень доктора наук, проводится ежегодно, начиная с 1958 года. В Канаде аналогичное обследование в пилотном варианте было осуществлено в 2003 году в университетах двух городов: Торонто и Монреаля. С 2004 года такие обследования стали ежегодными [2, 3]. В обеих странах их объектом являются все доктора наук, удостоенные степени в национальных университетах в период с 1 июля предыдущего года по 30 июня года текущего. При этом канадское обследование даже шире американского - оно предполагает некоторые дополнительные вопросы.

\footnotetext{
* Автор выражает признательность Джоан Баррелли (Национальный научный фонд США) за предоставление данных американского обследования присвоения докторских степеней. Автор несет ответственность за интерпретацию этой информации. Любые выводы, представленные в статье, отражают мнение самого автора, а не Канадского промышленного агентства или Правительства Канады.
} 
Таблица 1. Статус гражданства получателей докторских степеней в Канаде и США в 2003-2004 годах (проценты)

\begin{tabular}{l|r|r|}
\hline & Канада & CIIIA \\
\hline Гражданин & 82 & 67 \\
\hline $\begin{array}{l}\text { Негражданин, постоянный } \\
\text { резидент }\end{array}$ & 7 & 4 \\
\hline Негражданин, временная виза & 11 & 29 \\
\hline
\end{tabular}

Исследователи ставят своей целью анализ сопоставимых для США и Канады показателей карьерного роста докторов наук, однако на сегодняшний день в этом направлении сделано немногое. Первые три таких параметра на базе результатов канадского и американского обследований за 2004 год содержатся в работе Л. Ориоль [1] ${ }^{1}$.

Нами предпринята попытка представить индикаторы подготовки докторов наук и их дальнейших карьерных планов после получения ученых степеней. Значительное внимание уделено мобильности иностранных студентов - их иммиграции в Канаду и США для прохождения докторских программ и отъезду из страны после этого.

\section{Обобщенные показатели}

В период с 1 июля 2003 года по 30 июня 2004 года, по оценкам Статистической службы Канады [4], в университетах страны докторской степени были удостоены около 3600 человек, тогда как в США - 40710 человек [5], т.е. в процентном соотношении - 8:92. Следует, однако, учитывать, что на 1 июля 2004 года население Канады составляло 9.6\% от совокупной численности населения двух рассматриваемых здесь стран. Та же пропорция справедлива и для возрастной категории 30-34 года, считающейся наиболее типичной для получения докторской степени. Таким образом, в суммарном для двух стран выпуске докторов наук доля Канады по сравнению с США довольно незначительна.

\section{Качество подготовки}

Важные показатели вклада образовательного сектора в развитие национальных инновационных систем - количество специалистов, получивших степень доктора наук, а также качество их подготовки. Оценить последнее трудно, однако ориентиром может служить место университета, присвоившего докторскую степень, в международном рейтинге. В данной работе использован рейтинг, составленный Шанхайским университетом Jiao Tong. Думается, не имеет смысла оспаривать тот факт, что докторская степень, присужденная ведущим университетом Северной Америки-
Таблица 2. Доли граждан зарубежных стран в общей численности получателей степени доктора наук в Канаде и США в 2003-2004 годах (проценты)

\begin{tabular}{|l|r|l|r|}
\hline \multicolumn{1}{|c|}{ Канада } & & \multicolumn{2}{c|}{ США } \\
\hline США & 10.6 & Китай & 24.7 \\
\hline Китай & 10.3 & Южная Корея и КНДР & 11.1 \\
\hline Франция & 8.2 & Индия & 7.7 \\
\hline Великобритания & 6.9 & Тайвань & 5.4 \\
\hline Иран & 4.8 & Канада & 4.6 \\
\hline
\end{tabular}

Гарвардским, имеет больший вес, нежели степень, полученная после обучения по аналогичной программе в Университете Торонто, занимающем 19-е место в той же Северной Америке 2 .

Первую десятку рейтинга самых престижных университетов США составляют в основном частные учебные заведения и лишь один государственный - Университет Беркли, Калифорния. Во второй же десятке - семь университетов, финансируемых государством. Среди них Университет Торонто, котирующийся седьмым среди государственных, 19-м - среди всех университетов Северной Америки и 24-м - в мире. Отметим, что из 25 лучших университетов мира 20 находятся в Северной Америке, 3 - в Великобритании и 2 - в Японии.

В 2003-2004 годах 20 наиболее престижных университетов США присвоили докторские степени 8732 студентам, что составило $21 \%$ от общего числа степеней, присужденных всеми университетами США в этот период. В Университете Торонто докторские степени ежегодно получают примерно 550 человек - 5\% от общего числа докторов наук, выпускаемых престижными университетами Северной Америки. В указанный период девять самых престижных университетов США, получающих государственное финансирование, вручили дипломы докторов наук 4278 ученым. Таким образом, на Университет Торонто приходится примерно 11\% общего числа докторских степеней в десяти ведущих государственных университетах Северной Америки. Отсюда следует, что среди 20 наиболее престижных североамериканских университетов доля канадских учебных заведений в присвоении степеней докторов наук невелика, но в десятке лучших университетов, получающих государственное финансирование, эта доля значительна.

\section{Гражданство обладателей}

Не все докторские степени, присуждаемые в какойлибо стране, вручаются ее гражданам (табл. 1). Так, в Соединенных Штатах в 2003-2004 годах их граждане

\footnotetext{
${ }^{1}$ См. также статью Л. Ориоль в журнале «Форсайт», 2007, № 3 [прим. ред.].

2 Любое ранжирование университетов - вещь в достаточной степени условная и во многом зависит от того, какие критерии поставлены во главу угла при его формировании. В работе [6, с. 30] показано, что «в случаях, когда применяются разные схемы ранжирования для оценки относительных позиций институтов в стране, оказывается, что некоторые из них инвариантно занимают верхние строки... Несмотря на совершенно различные схемы взвешивания и агрегирования, используемые в национальных и международных рейтингах, такие университеты смогли последовательно монополизировать высшие ранги». Авторами приведен удельный вес критериев при составлении тех или иных рейтингов. В рейтинге, составляемом Шанхайским университетом Jiao Тong, наибольшее значение (90\%) придается результативности проводимых в университетах научных исследований, другие $10 \%$ отводятся собственно качеству обучения. Исходя из этого, данный рейтинг представляется наиболее релевантным для оценки качества докторских программ.
} 
Таблица 3. Доля граждан зарубежных стран, получивших докторскую степень в 20 ведущих университетах США в 2003-2004 годах (пройенты)

\begin{tabular}{|l|r|}
\multicolumn{1}{c|}{ Гражданство } & Доля \\
\hline США & 20 \\
\hline Китай & 21 \\
\hline Южная Корея и КНДР & 20 \\
\hline Индия & 20 \\
\hline Тайвань & 23 \\
\hline Канада & 33 \\
\hline Прочие & 22 \\
\hline Всего & 21 \\
\hline
\end{tabular}

получили 67\% докторских званий; для Канады соответствующий показатель достигал $82 \%$, а доля неграждан была значительно меньше, чем в США³.

Данные таблицы 1 позволяют рассчитать долю докторов наук среди граждан США и Канады. В рассматриваемый период университеты Канады присудили степень доктора примерно 2950 канадским гражданам. Это соответствует уровню выпуска докторов наук $0.7 \%{ }^{4}$. В то же время 601 канадец получил докторскую степень в университетах США, что соответствует 17\% канадцев, ставших докторами наук в 2003-2004 годах. С учетом этих реципиентов показатель для Канады возрастает до $0.8 \%$, для США он составляет $0.6 \% 5$. В итоге процент докторов наук среди канадских граждан выше, чем среди американских.

Итак, 17\% докторских степеней, полученных канадцами в 2004 году, приходятся на США. Для сравнения: в 2003 году в университетах Китая стали докторами наук 18806 ученых [6], а в американских университетах-
2784 гражданина Китая. Таким образом, до 13\% граждан Китая, обладающих докторской степенью, получают ее в университетах одной из двух изучаемых нами стран. Это верно, если исходить из допущения, что в университетах Китая почти все докторские степени были присуждены китайским гражданам. Видно, что, несмотря на значительную географическую удаленность и языковые барьеры, показатель Китая (13\%) близок к канадскому (17\%). По данным канадского обследования, в 2003 году в университетах Канады звания докторов присвоены 100 китайским гражданам. Следовательно, доля Канады в совокупном присуждении университетами обеих стран докторских степеней гражданам Китая - менее 4\%. Это также свидетельствует о том, что США более привлекательны для иностранцев, чем Канада, в плане реализации докторских программ, хотя обе североамериканские страны располагают университетами высокого уровня с преподаванием на английском языке.

В таблице 2 приведены доли зарубежных стран, граждане которых в наибольших масштабах претендуют на получение докторской степени соответственно в Канаде и США. Как видим, в случае США первые четыре места занимают азиатские страны - Китай, Корея, Индия и Тайвань. На них в совокупности приходится почти половина докторских дипломов, полученных иностранцами в Соединенных Штатах. Канадцы занимают пятое место. Что же касается самой Канады, то там наибольшую часть иностранных реципиентов степени доктора составляют американцы, далее следуют граждане Китая, Франции, Великобритании и Ирана.

Анализ таблиц 1 и 2 показывает, что в Канаде доля иностранцев среди реципиентов докторской степени значительно ниже, чем в США, и что Канада в этом плане для граждан Китая, Индии и Кореи не столь привлекательна, как США.

Таблиц 4. Распределение получателей докторских степеней - граждан и иностранцев - по областям науки: 2003-2004 (процеенть)

\begin{tabular}{|c|c|c|c|c|c|c|}
\hline \multirow[b]{2}{*}{ Науки } & \multicolumn{3}{|c|}{ Канада } & \multicolumn{3}{|c|}{ CIIA } \\
\hline & граждане & иностранцы & $\begin{array}{c}\text { удельный вес } \\
\text { иностранцев } \\
\text { в численности } \\
\text { получателей } \\
\text { докторской } \\
\text { степени }\end{array}$ & граждане & иностранцы ${ }^{* *}$ & $\begin{array}{c}\text { уделыный вес } \\
\text { иностранцев } \\
\text { в числености } \\
\text { получателей } \\
\text { докторской } \\
\text { степени }\end{array}$ \\
\hline О жизни & 30 & 22 & 18 & 22 & 20 & 28 \\
\hline Технические & 9 & 27 & 46 & 8 & 29 & 60 \\
\hline Естественные & 13 & 25 & 37 & 12 & 22 & 44 \\
\hline Общественные & 21 & 7 & 9 & 18 & 10 & 19 \\
\hline Гуманитарные & 15 & 9 & 16 & 16 & 7 & 16 \\
\hline Прочие & 12 & 10 & 20 & 25 & 12 & 17 \\
\hline Всего & 100 & 100 & 23 & 100 & 100 & 29 \\
\hline
\end{tabular}

* Обладатель временной рабочей визы или иностранный студент при первоначальной регистрации в докторской программе.

** Не имевший статуса гражданина США или постоянного резидента на момент получения докторской степени.

\footnotetext{
${ }^{3}$ Такая оценка не вполне корректна, поскольку $23 \%$ специалистов, получивших докторскую степень в университетах Канады, начинали обучение по докторской программе, пребывая в стране в качестве студента либо на основании временной рабочей визы. К моменту присуждения степени более половины таких специалистов (12\%) приобрели гражданство или статус постоянного резидента. В США аналогичная статистика не ведется.

${ }_{4}^{4}$ Уровень выпуска рассчитывается как отношение численности лиц, получивших докторскую степень в течение года, к суммарной численности населения в пятилетнем возрастном интервале 30-34 лет, умноженное на 5.

${ }^{5}$ Вкладом Канады в совокупное число докторских степеней, присужденных американским гражданам в университетах обеих рассматриваемых стран (100 чел.), можно пренебречь.
} 
таблица 5. Распределение специалистов, получивших докторскую степень в университетах США в 2003-2004 годах, по гражданству и области науки (процеены)

\begin{tabular}{|c|c|c|c|c|c|c|}
\hline \multirow{2}{*}{ Гражданство } & \multicolumn{6}{|c|}{ Науки } \\
\hline & о жизни & технические & естественные & общественные & гуманитарные & другие \\
\hline США & 21 & 8 & 11 & 19 & 15 & 26 \\
\hline Китай & 23 & 38 & 27 & 4 & 2 & 6 \\
\hline Индия & 26 & 36 & 19 & 8 & 3 & 8 \\
\hline Корея & 14 & 35 & 15 & 10 & 10 & 17 \\
\hline Тайвань & 18 & 21 & 14 & 8 & 11 & 28 \\
\hline Канада & 24 & 10 & 16 & 18 & 18 & 15 \\
\hline Прочие & 19 & 20 & 22 & 14 & 12 & 13 \\
\hline
\end{tabular}

Как уже отмечалось, 20 ведущих университетов (согласно упомянутому международному рейтингу) обеспечили пятую часть всех докторских званий, присужденных в США в 2004 году. В таблице 3 отражен процент докторов наук, получивших свою степень в этих университетах, - как самих американцев, так и граждан упомянутых пяти стран, на долю которых приходится наибольшее число иностранных реципиентов докторской степени в США. Из таблицы следует, что в лучших университетах степень получают $20 \%$ американских граждан; аналогичная либо чуть более высокая доля характерна для представителей четырех из пяти указанных иностранных государств, но для канадцев она намного выше - 33\%. Повышенный процент последних в ведущих университетах можно объяснить доступностью как минимум одного из двадцати лучших университетов и других высококачественных докторских программ в самой Кана-

\begin{tabular}{|c|c|}
\hline \multicolumn{2}{|c|}{$\begin{array}{c}\text { Таблица 6. Удельный вес докторов технических наук, } \\
\text { получивших степень в одном из } \\
20 \text { ведущих технических университетов США, } \\
\text { в общем их числе в 2003-2004 годах по гражданству } \\
\text { (проценты) }\end{array}$} \\
\hline Гражданство & Доля \\
\hline США & 44 \\
\hline Китай & 30 \\
\hline Южная Корея и КНДР & 51 \\
\hline Индия & 37 \\
\hline Тайвань & 54 \\
\hline Канада & 59 \\
\hline Прочие & 37 \\
\hline Всего & 40 \\
\hline
\end{tabular}

де. Это означает, что канадские граждане, вероятно, будут учиться на родине, если не поступят в лучшие университеты США. Если в 2003-2004 годах 20 самых престижных американских университетов присвоили степени докторов 202 канадским гражданам, то Университет Торонто (единственный канадский университет из двадцатки лучших) в тот же период объявил докторами наук более 400 канадцев ${ }^{7}$. Как представляется, они стремятся попасть на докторские программы в американский университет, только если он входит в престижную двадцатку; в противном случае они предпочтут остаться в Канаде.

\section{Области науки}

Рассмотрим теперь области знаний, в которых канадские и американские университеты присваивают степени докторов наук собственным и иностранным гражданам ${ }^{8}$. Для обеих стран характерна более высокая концентрация иностранных докторов в сфере технических и естественных наук по сравнению с гражданами либо постоянными резидентами (табл. 4). В США на долю иностранцев приходится до $60 \%$ докторских степеней, присужденных в технических науках, и до 44\% - в области естественных наук. Эти показатели для Канады составляют 46 и $37 \%$ соответственно. В то же время в сфере общественных и гуманитарных наук в обеих странах контингент иностранцев со степенью по численности сопоставим с гражданами и постоянными резидентами. В США отмечается низкая доля иностранных докторов наук в педагогике, а в Канаде в области наук о жизни.

Таблица 5 демонстрирует распределение по областям знаний специалистов, получивших дипломы докторов наук в американских университетах - граждан США, пяти государств, имеющих там наибольший иностранный контингент, и других стран. Видно, что канадцы, ставшие докторами в США, представлены столь же широко, как и те, кто

${ }^{6}$ Помимо Университета Торонто, в рейтинг 100 ведущих университетов мира включены другие три канадских университета - Британской Колумбии, Макгилл, МакМастер.

${ }^{7}$ Оценка автора. В Университете Торонто докторские степени ежегодно получают более 500 чел., из них $80 \%$ - граждане Канады.

${ }^{8}$ В канадском обследовании под «иностранными студентами» понимаются те специалисты, которые, начиная обучение по докторской программе, пребывали в стране по временной студенческой или рабочей визе (к не «иностранным студентам» относятся граждане Канады либо постоянные резиденты). Информация о докторах наук США относится либо к иностранным гражданам, имеющим временную визу (остальные - граждане США или постоянные резиденты) либо ко всем иностранным гражданам (прочие являются гражданами США) 
Таблица 7. Доля специалистов, получивших степень доктора наук в США в 2003-2004 годах и планирующих дальнейшее обучение, по областям науки (проц̧енты)

\begin{tabular}{|c|c|c|c|c|c|c|}
\hline Науки о жизни & $\begin{array}{c}\text { Технические } \\
\text { науки }\end{array}$ & $\begin{array}{c}\text { Естественные } \\
\text { науки }\end{array}$ & $\begin{array}{c}\text { Общественные } \\
\text { науки }\end{array}$ & $\begin{array}{c}\text { Гуманитарные } \\
\text { науки }\end{array}$ & Другие & Всего \\
\hline 67 & 36 & 56 & 31 & 12 & 6 & 35 \\
\hline
\end{tabular}

получают степень у себя на родине, равно как и граждане США (за исключением низкой доли докторов наук в прочих отраслях, прежде всего в области образования).

Иная картина характерна для граждан других стран. Так, более трети иностранцев, получивших докторские степени и являющихся гражданами Китая, Индии и Кореи, - «технари». Совокупная доля наук о жизни, технических и естественных наук составляет: для граждан Китая - 88\%, Индии - 82, Кореи - 64, Тайваня - 61, но только 50 - для Канады и 41\% - для США.

Интересно сравнить распределение по областям знаний граждан Китая, получивших докторскую степень в США, с теми, кто получил ее в китайских университетах в 1999-2003 годах [7]. Так, в Китае 38\% докторских степеней присуждено в технических науках, 22 - в естественных, 4 - в сельскохозяйственных и $15 \%$ - в медицине (последние две области в таблице 5 включены в рубрику наук о жизни). Процент докторских степеней в технических науках тот же, что и в американских университетах (табл. 5); совокупная доля естественных, сельскохозяйственных и медицинских дисциплин (42\%) несколько ниже, чем в первом случае (50\%). В Китае, как и в Канаде, отраслевая структура численности специалистов, получивших докторскую степень в национальных университетах, схожа с той, что сложилась среди граждан этих стран, получивших степень в одном из американских университетов.

\section{Технические науки}

Отрасль технических наук заслуживает особого рассмотрения - она привлекает в США и Канаду огромную массу претендентов на докторскую степень из азиатских стран, и в то же время в ней весьма низок процент собственных граждан. Как свидетельствует таблица 4, 60\% докторских дипломов по техническим наукам предоставляются в США иностранцам с временными рабочими или студенческими визами. Фактически, в составе этой цифры 21\% приходится на граждан Китая, другие $18 \%$ - на выходцев из Индии, Кореи и с Тайваня.
Шанхайский университет Jiao Tong составляет не только общий рейтинг университетов мира, но и классифицирует их по областям знаний. Один из разделов классификации - технические науки и информатика 9 . Как и в сводном рейтинге, университеты Северной Америки занимают здесь ведущие позиции. Так или иначе, Университет Торонто (19-е место в целом и 17-е - в Северной Америке) остается единственным представителем Канады в двадцатке наиболее престижных североамериканских университетов. Интересно, что североамериканские университеты, находящиеся на государственном финансировании, в плане технических наук котируются гораздо выше, чем в общем рейтинге: им принадлежат семь из десяти ведущих мест в мире, тогда как в целом в десятку лучших входит только один государственный университет.

В таблице 6 отражена структура докторских степеней в области технических наук, присужденных двадцатью лидирующими университетами гражданам США, представителям «ведущей пятерки» зарубежных стран, а также выходцам из других государств. Уровень концентрации докторских степеней по техническим наукам в двадцати университетах-лидерах в этой сфеpe $(40 \%)$ почти вдвое выше, чем всех таких дипломов в ведущей двадцатке из общего рейтинга. Что касается распределения докторских степеней по гражданству их обладателей, то процент американцев немного, а граждан Кореи, Тайваня и Канады - значительно выше, чем индусов и китайцев.

Как и в случае общего рейтинга, наивысшую долю канадских докторов технических наук можно объяснить наличием в Канаде достаточного количества высококачественных инженерных образовательных программ, поскольку канадцы покидают свою страну только в поисках программ высочайшего класса. Напомним: Университет Торонто ранжируется 17-м в Северной Америке и 19-м - в мире. В список 100 лучших технических университетов мира входят еще четыре представителя Канады - университеты Макгилл, Ватерлоо, Британской Колумбии и Монреаля.

Таблица 8. Возраст при получении степени доктора наук в университетах Канады и США в 2003-2004 годах (лет)

\begin{tabular}{|c|c|c|c|c|c|c|}
\hline & Науки о жизни & $\begin{array}{c}\text { Технические } \\
\text { науки }\end{array}$ & $\begin{array}{l}\text { Естественные } \\
\text { науки }\end{array}$ & $\begin{array}{c}\text { Общественные } \\
\text { науки }\end{array}$ & $\begin{array}{c}\text { Гуманитарные } \\
\text { науки }\end{array}$ & Другие \\
\hline $\begin{array}{l}\text { Канада } \\
\text { (средний) }\end{array}$ & 34 & 35 & 32 & 36 & 38 & 44 \\
\hline $\begin{array}{l}\text { США } \\
\text { (средний) }\end{array}$ & 35 & 36 & 34 & 36 & 38 & 44 \\
\hline $\begin{array}{l}\text { США } \\
\text { (медиана) }\end{array}$ & 32 & 31 & 31 & 33 & 35 & 41 \\
\hline
\end{tabular}

${ }^{9}$ Как в канадском, так и в американском обследованиях информатика и математика включены в категорию «Естественные науки». 
Таблиц 9. Распределение лиц, получивших степень доктора наук в университетах США и Канады в 2003-2004 годах и имеющих определенные планы трудоустройства по секторам занятости (процценть)

\begin{tabular}{|c|c|c|c|c|c|c|}
\hline & $\begin{array}{c}\text { Науки } \\
\text { о жизни }\end{array}$ & $\begin{array}{l}\text { Технические } \\
\text { науки }\end{array}$ & $\begin{array}{l}\text { Естествен- } \\
\text { ные науки }\end{array}$ & $\begin{array}{c}\text { Обществен- } \\
\text { ные науки }\end{array}$ & $\begin{array}{l}\text { Гуманитар- } \\
\text { ные науки }\end{array}$ & Прочие \\
\hline \multicolumn{7}{|c|}{ Канада } \\
\hline Образование & 39 & 37 & 44 & 51 & 79 & 84 \\
\hline Государственный сектор & 10 & 8 & 13 & 10 & 7 & 10 \\
\hline $\begin{array}{l}\text { Здравоохранение/ } \\
\text { социальные услуги }\end{array}$ & 16 & $\ldots$ & .. & 29 & $\ldots$ & $\cdots$ \\
\hline Частный сектор & 35 & $48^{*}$ & $37^{*}$ & $6^{*}$ & $10^{*}$ & $5^{*}$ \\
\hline \multicolumn{7}{|c|}{ США } \\
\hline $\begin{array}{l}\text { Сектор высшего образо- } \\
\text { вания }\end{array}$ & 53 & 22 & 45 & 60 & 84 & 57 \\
\hline Прочие & 9 & 5 & 5 & 15 & 10 & 33 \\
\hline Государственный сектор & 14 & 11 & 8 & 11 & 2 & 5 \\
\hline Промышленность & 24 & 62 & 42 & 14 & 4 & 6 \\
\hline
\end{tabular}

* По крайней мере один компонент частного сектора отсутствует по соображениям конфиденциальности.

Ведущими канадскими университетами присуждается небольшое количество докторских степеней по техническим наукам. В 2002-2003 годах Университет Торонто удостоил такими дипломами примерно 70 специалистов, из них 40 канадцев. Для сравнения: в 2003-2004 годах 58 канадских граждан получили степень доктора технических наук от одного из двадцати ведущих университетов США ${ }^{10}$. Это резко контрастирует с приведенной выше общей статистикой по присуждению докторских степеней, согласно которой в Университете Торонто стали докторами вдвое больше канадцев, чем в 20 лучших американских университетах, вместе взятых.

Высокий процент граждан Кореи и Тайваня, получивших степень доктора технических наук от одного из 20 ведущих университетов США, можно также отнести на счет качества докторских программ в этих странах, что часто стимулирует к обучению на родине в случае невозможности поступления на лучшие зарубежные программы. Среди сотни ведущих технических университетов мира по три представляют Южную Корею и Китай (за исключением Гонконга) и по два - Тайвань и Гонконг.

Судя по количеству докторских степеней, присуждаемых в Китае, три-пять технических университетов высокого уровня не способны принять всех китайских студентов, которые при благоприятном раскладе предпочли бы «остаться дома» ${ }^{11}$.

\section{Карьерные планы}

Получение докторской степени означает для ее обладателя начало нового этапа в карьере. Канадский опрос 2004 года показал, что 74\% докторов наук, ставших таковыми в изучаемый период, имели определенные планы после получения степени ${ }^{12}, 56 \%$ - имели работу, 44\% - намечали продолжить обучение. В США 70\% докторов выпуска 2003-2004 годов вынашивали определенные планы, 65 имели работу и 35\% намеревались продолжать обучение.

Таблица 7 отражает планы на дальнейшее обучение докторов наук, получивших эту степень в США. Из нее видна высокая распространенность постдокторского обучения в области наук о жизни и естественных наук, более низкая - в технических и общественных областях и совсем небольшая - в гуманитарных науках. По Канаде получить аналогичную информацию не удалось, однако тенденция там вряд ли оказалась бы иной.

Интересно сопоставить планы постдокторского образования с типичным возрастом получения докторской степени (табл. 8). Для обеих стран этот возраст практически одинаков, но в Канаде доктора в сфере естественных и технических наук оказываются несколько моложе своих американских коллег.

Возрастная медиана представляется наилучшим индикатором «типичного» возраста получения док-

\footnotetext{
${ }^{10}$ Оценка автора. По данным пилотного канадского обследования 2002-2003 годов, на долю технических наук приходится 13\% всех докторских степеней, присужденных Университетом Торонто за этот период. Всего в Университете присваивается около 550 докторских степеней ежегодно.

${ }^{11}$ Согласно данным, приведенным в работе [7], 38\% всех докторских степеней, присвоенных гражданам Китая в университетах этой страны в 2003 году (всего - 18 806), относятся к области технических наук, или, в абсолютном значении, 7100 человек. Это заметно больше, чем общее число докторских степеней в области технических наук, присужденных университетами США в том же году (5 619), но в Китае предлагается намного меньше высококачественных докторских программ.

12 В обоих обследованиях под «определенными планами» понимались планы возвращения в страну происхождения, продолжения карьеры в той области наук, по которой присвоена степень, смены специальности либо продолжения обучения. Для США подобная информация приведена с распределением по областям знаний. Наименьший процент докторов, имеющих определенные планы, отмечен в сфере технических наук, наиболее высокий (75\%) - в категории «другие» (педагогика и т.п.). Кроме того, по США доступна аналогичная информация с классификацией по гражданству: $72 \%$ - среди граждан США, 63 - постоянных резидентов, $66 \%$ обладателей временной визы.
} 
Таблица 10. Гражданство докторов наук, оставшихся в стране после получения степени в 2003-2004 годах (проценты)

\begin{tabular}{r|r|r|r|r|r|r|}
\hline \multicolumn{3}{|c|}{ Канада } & \multicolumn{3}{c|}{ США } \\
\hline \multirow{2}{*}{ гражданин } & $\begin{array}{c}\text { Двойное } \\
\text { гражданство }\end{array}$ & негражданин & гражданин & $\begin{array}{c}\text { постоянный } \\
\text { резидент }\end{array}$ & $\begin{array}{c}\text { временная } \\
\text { виза }\end{array}$ \\
\hline 83 & 82 & 61 & 92 & 94 & 69 \\
\hline
\end{tabular}

торской степени. Этот показатель имеется и по США (табл. 8). Однако вне зависимости от используемого измерителя типичный возраст получения докторской степени выше для сферы общественных, гуманитарных и прочих наук, чем в науках о жизни, технических и естественных.

Подобная оценка тем не менее может ввести в заблуждение относительно возраста, в котором доктор наук начинает рабочую карьеру, поскольку в науках о жизни и естественных науках наиболее высок процент докторов, планирующих продолжить обучение. Несколько лет, проведенных этими специалистами на постдокторских программах, означают, что они, вероятно, начнут работать в том же возрасте, что и новоиспеченные доктора в общественных и гуманитарных науках.

\section{Сектор занятости}

Таблица 9 представляет данные о распределении получателей степени доктора наук, имеющих определенные карьерные планы, по секторам занятости ${ }^{13}$. Несмотря на неполную сопоставимость классификаций секторов, некоторые выводы напрашиваются сами собой. Областью знаний с самым высоким процентом занятости в частном секторе в обеих странах являются технические науки, затем следуют естественные и науки о жизни. В социальных и гуманитарных науках ${ }^{14}$ доля занятости в частном секторе низка.

Образовательная сфера предстает основным работодателем для докторов-гуманитариев. Процентное соотношение докторов, идущих в систему образования, тоже во многом схоже. К категории «Прочие»в данной таблице отнесена система начального и среднего школьного образования. Заметные различия между странами отмечаются в области наук о жизни и технических наук ${ }^{15}$.

\section{Место жительства}

Теперь зададимся вопросом: где именно доктора наук планируют реализовывать свои дальнейшие намерения? В таблице 10 отражены планы выбора местожительства лицами с докторскими степенями, полученными в Канаде и США. Удельный вес докторов, не собирающихся покидать Канаду, для двух их категорий - граждан Канады и лиц с двойным гражданст- вом - почти идентичен. Но этот процент меньше доли американских граждан, которые намерены остаться в США. Даже несмотря на охват постоянных резидентов, удельный вес иностранцев, планирующих остаться в Канаде, ниже процента обладателей докторских степеней, которые имеют временные визы и намерены остаться в США.

Из числа тех, кто планирует покинуть Канаду (включая граждан и не граждан), 63\% собираются переехать в США. С другой стороны, среди докторов, получивших степени в Канаде, 23\% начинали обучение по докторским программам, находясь в стране по временной визе; 21\% - планируют уехать из Канады. В результате миграционная выгода от докторского образования оказывается для Канады незначительной.

Рассмотрим планы миграции иностранных докторов наук, получивших степень в США в 2003-2004 годах, в зависимости от гражданства и рейтинга университетской программы. Таблица 11 отражает доли иностранцев, получивших степени в 20 ведущих либо в прочих американских университетах и планирующих остаться в США. Различия между этими двумя категориями для граждан одной и той же страны несущественны. Наиболее высокие проценты - среди представителей Китая и Индии, но и для других стран «пятерки» (за исключением Тайваня) характерны достаточно существенные показатели (не менее 60\%).

\section{Заключение}

Канада и США имеют общую границу, высокоинтегрированные и развитые экономические системы. В обеих странах существует большое число превосходных университетов. Канадские университеты, финансируемые из федерального бюджета, имеют достаточно благоприятные позиции на фоне аналогичных американских, хотя наивысшие места в рейтингах занимают частные университеты США.

Чем объяснить повышенную, по сравнению с Канадой, привлекательность докторских программ в США для студентов, приезжающих из других частей света? Несомненно, одна из причин в том, что в США находятся самые престижные в мире университеты. В то же время многие иностранцы получают докторские степе-

\footnotetext{
${ }^{13}$ Классификация по секторам для Канады и США не идентична. В Канаде все образовательные услуги объединены в единую категорию (в таблице - «Образование»); в США начальные и средние школы относятся к категории «Прочие», где они доминируют наряду с некоммерческими организациями. В Канаде различают здравоохранение и социальные услуги, которые в США, по-видимому, распределены между государственным, частным и прочими секторами. В Канаде выделяются различные компоненты частного сектора, что и отражено в таблице.

${ }^{14}$ Высокий процент докторов общественных наук в секторе здравоохранения и социальных услуг объясняется тем, что психология - основной компонент в данной области знаний. Указанные сферы в Канаде преимущественно контролируются госсектором.

${ }^{15}$ К категории «Прочие» относятся преимущественно доктора в области наук об образовании.
} 


\section{Таблица 11. Иностранцы, получившие докторские степени в университетах США \\ в 2003-2004 годах и планирующие остаться в СШІ (проценты)}

\begin{tabular}{|l|r|r|}
\hline \multirow{2}{*}{ Гражданство } & \multicolumn{2}{|c|}{ Университеты СІІА } \\
\cline { 2 - 3 } & $\begin{array}{c}\text { 20 самых } \\
\text { престижных }\end{array}$ & Прочие \\
\hline Китай & 92 & 94 \\
\hline Южная Корея и КНДР & 74 & 72 \\
\hline Индия & 90 & 92 \\
\hline Тайвань & 68 & 45 \\
\hline Канада & 63 & 64 \\
\hline
\end{tabular}

ни в университетах, которые зачастую стоят в рейтингах ниже канадских.

Другая очевидная причина в том, что для многих иностранных студентов Соединенные Штаты более привлекательны из-за лучших перспектив трудоустройства после окончания обучения. Ранее уже отмечалось ухудшение ситуации на рынке труда в 1990-е годы для докторов философии в Канаде по сравнению с США [2] ${ }^{16}$. Напрашивается вывод: для многих студентов решение пройти докторское обучение за границей означает также намерение остаться там работать. Важно отметить, что более 90\% обладателей докторских степеней из Индии и Китая планируют остаться в США после окончания обучения по крайней мере на начальном этапе. В то время как доктора наук весьма мобильны между Канадой и США [2], преимущества юридического статуса резидента США и знания американского рынка труда очевидны.

Другой примечательный факт, выявленный в ходе исследований: более высокая по сравнению с канадскими и американскими гражданами концентрация докторов, не являющихся гражданами этих стран, в сфере технических, естественных наук и наук о жизни. Особенно резок контраст в технических науках, на долю которых приходится менее 1/10 части ученых с докторской степенью среди канадских и американских граждан и более четверти докторов среди тех, кто не является таковыми. В университетах США 60\% докторов технических наук составляют иностранцы.

Масштабное развитие научных исследований и инновационной деятельности в Северной Америке во многом обусловлено привлекательностью американских университетов для получения докторской степени в области естественных и технических наук, а также перспектив последующего трудоустройства в США.

Сохранится ли такая ситуация? На основе представленных индикаторов можно сделать следующее заключение: по мере роста доходов населения и развития университетов в азиатских странах, которые являются крупными поставщиками иностранных студентов для североамериканских докторских программ, граждане этих стран будут все чаще предпочитать оставаться на родине для обучения и последующей работы. Хотя таких стран немного, для тех из них, в которых население имеет более высокие доходы, чем в Китае и Индии, процент специалистов с дипломом доктора наук, которые планируют покинуть США после окончания обучения, выше.

Справедливо и то, что, по мере улучшения в отдельных странах качества университетского образования растет и концентрация граждан этих стран, получивших докторские степени в самых престижных американских университетах. Так происходит потому, что, когда высококачественные докторские программы доступны «дома», даже если студент изначально предпочитает обучаться за границей, он покинет страну только ради лучших возможностей. Отсюда следствие: если число мест в национальных высококлассных докторских программах растет, все меньше будет поток отправляющихся на докторское обучение за границу.

Таким образом, Северной Америке будет все труднее привлекать иностранцев для прохождения докторского обучения и удерживать их у себя по завершении программ, особенно в сферах естественных и технических наук.

1. Auriol L. Labour Market Characteristics and International Mobility of Doctorate Holders: The Case of Five OECD Countries. Paris: OECD, 2006.

2. Boothby D., Lau B., Songsakul T. The PhD Labour Market in Canada, Draft. Mimeo. 2007.

3. Gluszynski T., Peters V. Survey of Earned Doctorates: A Profile of Doctoral Degree Recipients. Ottawa: Statistics Canada, 2005.

4. Hoffer T.B., Welch V., Williams K., Hess M., Webber K., Lisek B., Loew D., Guzman-Barron I. Doctorate Recipients from United States Universities: Summary Report 2004. Chicago: NORC at the University of Chicago, 2005.

5. Survey of Earned Doctorates: July 1, 2003 to June 30, 2004. Ottawa: Statistics Canada, 2005

6. Usher A., Savino M. A Global Survey of Rankings and League Tables. In: College and University Ranking Systems: Global Perspectives and American Challenges. Washington, D.C.: Institute for Higher Education Policy, 2007.

7. Weiguo S., Zhaohui X. Preliminary Analysis of China's Doctor Education. Paper for the NESTI Workshop on User Needs for Indicators on Careers of Doctorate Holders, Paris, 27 September 2004. Beijing: National Research Center for Science and Technology Development, 2004.

\footnotetext{
${ }^{16}$ В работе [2] используются данные переписей с целью изучения занятости и зарплат докторов наук в Канаде и США, а также их мобильности между этими двумя странами. Основные выводы следующие: 1) процент занятости докторов наук в США значительно выше, чем в Канаде, при этом в американском секторе образования их концентрация существенно ниже, нежели в канадском; 2) доходы докторов наук в США как в абсолютном выражении, так и по темпам роста в 1990-е годы многократно превышают заработки их канадских коллег; 3) отмечена интенсивная мобильность докторов наук между Канадой и США; 4) в Канаде по сравнению с США более высок процент докторов наук иностранного происхождения, что, впрочем, не является причиной существенной разницы в доходах докторов наук в этих двух странах; 5) наиболее вероятная причина такого разрыва - в более медленном росте спроса на докторов наук в Канаде, чем в США; 6) разрыв в уровнях доходов докторов наук Канады и США увеличивался на протяжении 1990-х годов, несмотря на их значительную трудовую мобильность. Возможные объяснения: разница в качестве подготовки докторов наук; снижение доходов у тех докторов наук, которые лишь недавно иммигрировали в США; сильная ориентированность на свою страну у канадских докторов наук.
} 